\title{
Assessment of Surface Water Quality in the Damietta Branch of Nile River, Egypt
}

\author{
Ibrahim H. Smysem ${ }^{1 *}$, Abdel-Aziz A. Khidr², Mohamed H. Bahnasawy², Mohamed M. El-Komi . \\ 1 Central lab for drinking water researches, Damietta drinking water company, Damietta, Egypt. \\ 2 Zoology Department, Faculty of Science, Damietta University, Damietta, Egypt. \\ 3 National Institute of Oceanography and Fisheries, Alexandria, Egypt.
}

Received: 20 August 2020 /Accepted: 17 October 2020

*Corresponding author's E-mail: Ibrahimsmysem@gmail.com

\begin{abstract}
The major aim of the present study is to evaluate the surface water quality at a part of the Damietta branch, Nile River of Egypt via the measurement of some physicochemical parameters followed by calculation of water quality index (WQI). WQI is considered a simple and effective tool successfully applied for the assessment and investigation of the status and quality of the surface water in any ecosystem. A total of 21 parameters was monitored and measured at ten stations for a year from January to December 2014. Correlation coefficients for physicochemical parameters showed that only turbidity, dissolved oxygen, biochemical oxygen demand, ammonia, and silicate had spatial significant variability. Almost the highest average values appeared at station III. The calculated WQI manifested that the highest value was $66.70 \%$ at station IX, while the lowest was $56.44 \%$ at station III. One-way analysis of variance (ANOVA) showed that water quality in the autumn season was higher than the summer months while the spatial significant variability of the WQI confirmed that the St.III. recorded the worst sites, while the sites of the East Bank had; almost the highest average values appeared Generally, most stations found in a medium quality. Damietta branch eastern bank was better than the western one. The mean values of most measured parameters were within the threshold limits in comparison to Egyptian environmental standards regularities (EESR). WQI will be useful mechanism for regular monitoring.
\end{abstract}

Keywords: Nile River, Damietta Branch, Water Quality index, Spatial variations.

\section{Introduction}

Surface waters are the most exposable to direct pollution due to their easy accessibility for disposal of pollutants. Waterways like rivers assume an imperative significant job in the development of a nation's economy. Rivers are not only restricted to the source of drinking water, but also incorporated filling different needs for example: fishing, navigation, industry, irrigation and generation of hydropower [1]. The Nile River is considered the lifeline and life artery of Egypt as well as chief primary fountain of palatable drinking water and irrigation. Throughout the Egyptian history the Nile had the dominating effects on be create the economy, culture, public health, social life and political aspects [2]. It passes along Egyptian land for about $950 \mathrm{~km}$ starting from downstream Aswan High Dam to 
upstream delta barrage, where it divides into two branches; Rosetta and Damietta branches. Each of which runs separately to the Mediterranean Sea, forming the delta region between both branches [3]. The river surface water quality is persuaded by some human activity such as agricultural, industrial, domestic and touristic activity along its banks from several sources at different regions upstream to downstream [4]. Egypt among other countries is unique in its dependence on water from deterministic source., therefore water quality is a matter of major concern. The quality of both untreated surface water and treated drinking water was the concern of experts in all countries of the world. Regrettably, the load affects directly or indirectly on the surface water quality which resembles the main source of drinking water in Egypt particularly at the inlet area of water treatment plants (WTPs). Environmental pollution is one of the most horrible crises that we are facing today. Self-purification and dilution concepts contribute to the gradual improvement in water quality of rivers [5]. The problem of polluted surface water has become a crucial issue due to the progression of industrial development, urbanization, and population growth [6]. The fresh surface water in Damietta is considered the only source for supplying WTPs with their row water. Damietta is known by terrible industry, where surrounding agricultural zones are affected by various pollution resources [7]. The nature and quality of water relies upon the area and the ecological condition of its sources at some random region. Water quality refers to the chemical, physical, biological and radiological characteristics of water [8]. It is a measure for the water condition comparative to the requirements of one or more biotic species and/or to any human need or purpose [9]. Water resources management as well as monitoring of water quality has been considered as a national responsibility for developing. Monitoring programs can provide a representative and reliable estimation of surface water profile via physicochemical parameters measurement. Regular sampling and estimation of numerous physicochemical parameters at different stations resulting in a large data matrix, which often used WQI evaluate the quality of water [10]. Spatial and temporal variations of physicochemical parameters were executed for water characteristics to put our hands on the water denaturation problems. The objective of the current study is basically aim to calculate WQI via measuring selected physicochemical parameters to summarize large amounts of tests and data into simple expression (e.g., excellent, medium, or bad). WQI is important to monitor and screen the water quality over a period of time in order to detect changes in the water's ecosystem. Numerous studies interested in measuring the surface water quality condition of riverine waters on the basis of both physicochemical characteristics and the calculation of WQI $[8,11,12]$.

\section{Material and Methods}

\section{Study Area \& Sampling Stations}

The area of study is located in Damietta district extend about $65 \mathrm{~km}$ of Damietta Branch of the Nile River, it located between East longitude $31^{\circ} 62^{\prime} 265^{\prime \prime}, 31^{\circ} 77^{\prime} 551^{\prime \prime}$ and North latitude $31^{\circ} 22^{\prime} 752^{\prime \prime}, 31^{\circ} 40^{\prime} 035^{\prime \prime}$ as shown in (Figure1). The study area divided into two main parts; western and eastern. Ten sampling stations were selected; four in the western bank of the study area. Station I and station II chosen near the hot water outlet of hydropower generation plant, while station III and station IV lied nearby some villages receiving domestic sewage. The rest stations located in the eastern bank in front of the inlet pipe of water treatment plans in stations (VIII, IX, and X.) Sampling collection was performed during the period from January to December 2014.

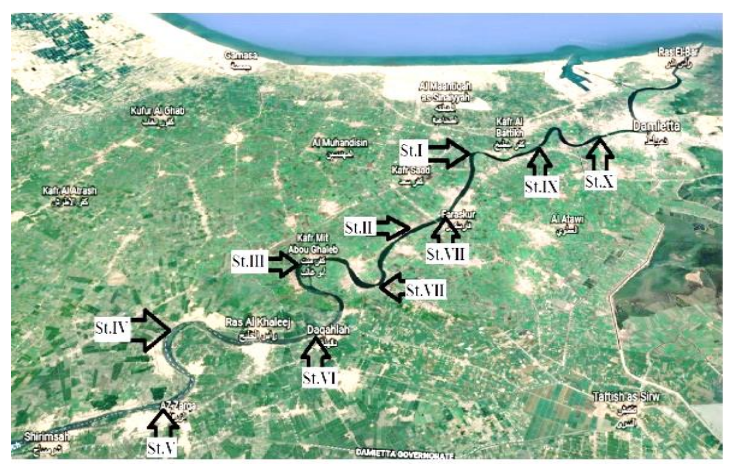

Figure 1: Geographic map of the study area showing the location of water sampling sites at Damietta region

\section{Water Samples Collection}

Surface water samples were collected monthly from central area of each site at depth of 20$30 \mathrm{~cm}$ using water sampler. Three clean 
polyethylene bottles were used; one for field measurements and other for laboratory analysis including BOD test, then cover firmly and stored at temperature below $4^{\circ} \mathrm{C}$. Some analysis carried out in situ, while the rest bottles were taken to the laboratory for the analysis of physicochemical parameters. Water sampling was carried out according to standard methods for examination of water and wastewater [13].

\section{Field Measurements}

Temperature, turbidity, $\mathrm{pH}$, dissolved oxygen, electrical conductivity and total dissolved solids of surface water were measured in situ by portable multi-probe water quality analyzers calibrated before used. Temperature was measured by a dry centigrade mercury thermometer graduated to $0.1^{\circ} \mathrm{C}(0-50)$ model GH ZEAL LTD and expressed in ${ }^{\circ} \mathrm{C}$. Turbidity was measured immediately at the time of the sampling in three replicates using a portable turbid-meter model WTWTURB-430T and expressed in NTU. pH values were measured using a digital portable $\mathrm{pH}$-meter model HANNA pH211. Dissolved oxygen was measured using a portable DO-meter (model JENCO 9173) and expressed in $\mathrm{mg} \mathrm{O}_{2} / \mathrm{l}$. Electrical conductivity and total dissolved solids were measured using multi-probe conductivity meter (Model WTW LF-315) expressed respectively in $\mathrm{mg} / \mathrm{l}$ and $\mu \mathrm{S} / \mathrm{cm}$.

\section{Laboratory Analysis}

According to standard methods for examination of water and waste water [14] Biochemical oxygen demand, chlorides, alkalinity were measured. Total, calcium and magnesium hardness in addition to macronutrients as ammonia, nitrite, nitrate, phosphate, and silicate were analyzed. The heavy metals (cadmium, iron, nickel and lead) were measured using the inductively coupled plasma-mass spectrometry 7000 with Perkin Elmer Optima3000, USA [15]. The instruments were calibrated premeasuring according to the manufacturer's guides. The obtained results were checked by standardization and sample duplication.

\section{WQI calculation}

WQI is a mathematical application provides a numerical single value resulted from multiple results of different parameters. The obtained values represent the level of water quality, which can be used for the comparison of water quality changes over a time in an ecosystem [16]. The standard formula is:

$$
\mathbf{W Q I}=\mathbf{k} \frac{\sum_{i} \mathbf{C}_{i} \mathbf{w}_{i}}{\sum_{i} \mathbf{w}_{i}}
$$

Where, $\mathbf{C}_{\mathbf{i}}$ is the value assigned to each measured parameter after normalization on a scale from 0 to 100 (Table 1) which Zero indicates water that is not suitable for the intended use and 100 represents perfect water quality. $\mathbf{k}$ is a subjective constant representing the visual impression of river water quality. In this study, $\mathbf{k}$ was ignored to prevent the introduce of subjective evaluation [17]. $\mathbf{W}_{\mathbf{i}}$ is the relative weight assigned to each water parameter. A maximum weight of 4 was assigned to parameters of relevant importance for aquatic life, while the lowest value was assigned to parameters with minor relevance [18]. These normalized values were translated into statement of water quality including excellent, good, medium, bad and very bad based on selection some physicochemical parameters [19].

\section{Statistical Analysis}

Descriptive statistics were calculated for the monitored parameters in the water samples. Pearson correlation coefficient was used to define the relationship between each two parameters. WQI was calculated using computerized application by MS-Excels sheets programs One-way ANOVA was applied to compare the spatial and temporal variation of WQI values. the statistical analysis was conducted using SSPS 22 for windows.

\section{Results and Discussion}

The premier step for evaluation that obtained results was compared with the permissible limits of EESR of article 60 of law No.48/1982. Regarding minimum standards for the quality of the Nile River water as well as the protection of the Nile River and waterways from pollution and its modification for article 50 of decision 92 October 2013 tabulated in (Table 2) 
Table 1: Parameters considered in WQI calculation adapted from Pesce et al.(2000) and Sanchez et al.( 2007). All values expressed in $\mathrm{mg} / \mathrm{l}$ except turbidity in NTU, temperature in ${ }^{\circ} \mathrm{C}$ and $\mathrm{pH}$ without unit.

\begin{tabular}{|c|c|c|c|c|c|c|c|c|c|c|c|c|}
\hline \multirow{2}{*}{ Parameters } & \multirow{2}{*}{$W_{i}$} & \multicolumn{11}{|c|}{ Normalization factor $\mathrm{C}_{\mathrm{i}}$} \\
\hline & & 100 & 90 & 80 & 70 & 60 & 50 & 40 & 30 & 20 & 10 & 0 \\
\hline Ammonia & 4 & $<0.01$ & $<0.05$ & $<0.10$ & $<0.20$ & $<0.30$ & $<0.40$ & $<0.50$ & $<0.75$ & $<1.00$ & $\leq 1.25$ & $>1.25$ \\
\hline DO & 4 & $\geq 7.5$ & $>7.0$ & $>6.5$ & $>6.0$ & $>5.0$ & $>4.0$ & $>3.5$ & $>3.0$ & $>2.0$ & $\geq 1.0$ & $<1.0$ \\
\hline BOD & 3 & $<0.5$ & $<2$ & $<3$ & $<4$ & $<5$ & $<6$ & $<8$ & $<10$ & $<12$ & $\leq 15$ & $>15$ \\
\hline Nitrite & 2 & $<0.005$ & $<0.01$ & $<0.03$ & $<0.05$ & $<0.10$ & $<0.15$ & $<0.20$ & $<0.25$ & $<0.50$ & $\leq 1.00$ & $<1.00$ \\
\hline Turb. & 2 & $<5$ & $<10$ & $<15$ & $<20$ & $<25$ & $<30$ & $<40$ & $<60$ & $<80$ & $\leq 100$ & $>100$ \\
\hline & 1 & $21 / 16$ & $22 / 15$ & $24 / 14$ & $26 / 12$ & $28 / 10$ & $30 / 5$ & $32 / 0$ & $36 /-2$ & $40 /-4$ & $45 /-6$ & $45 /<-6$ \\
\hline $\mathrm{PO}_{4}^{-3}$ & 1 & $<0.05$ & $<0.05$ & $<0.05$ & $<0.10$ & $<0.10$ & $<0.15$ & $<0.15$ & $<0.20$ & $<0.20$ & $<0.30$ & $<0.30$ \\
\hline pH & 1 & 7 & $7-8.5$ & $7-9$ & $6.5-7$ & $6.5-7$ & $6 .-9.5$ & $5-10$ & $4-11$ & $3-12$ & $2-13$ & $1-14$ \\
\hline
\end{tabular}

\section{Water Quality Parameters}

The physicochemical properties of collected surface water samples are summarized in (Table 3). The data were statistically analyzed using descriptive analysis (minimum, maximum, mean and standard deviation).

Table 2: Egyptian standard regulations of regularities of article 60/law No. 48/1982 regarding minimum standards for the quality of the Nile River

\begin{tabular}{l|l|l}
\hline Parameter & Permissible limits & Unit \\
\hline Temperature & $5^{0}$ cover usual & $\mathrm{C}^{\circ}$ \\
\hline Turbidity & - & $\mathrm{NTU}$ \\
\hline $\mathrm{pH}$ & $7-8.5$ & -- \\
\hline TDS & Not more than500 & $\mathrm{mg} / 1$ \\
\hline EC & - & $\mu \mathrm{S} / \mathrm{cm}$ \\
\hline DO & Not less than5 & $\mathrm{mg} / 1$ \\
\hline BOD & - & $\mathrm{mg} / 1$ \\
\hline chlorides & - & $\mathrm{mg} / 1$ \\
\hline Alkalinity & $20-150$ & $\mathrm{mg} / 1$ \\
\hline T.Hardness & - & $\mathrm{mg} / 1$ \\
\hline Ca.Hardness & - & $\mathrm{mg} / 1$ \\
\hline Mg.Hardness & - & $\mathrm{mg} / 1$ \\
\hline Ammonia & Not exceed than 0.5 & $\mathrm{mg} / 1$ \\
\hline Nitrite $(\mathrm{NO} 2)$ & - & $\mathrm{mg} / 1$ \\
\hline Nitrate $(\mathrm{NO} 3)$ & Not exceed than 45 & $\mathrm{mg} / 1$ \\
\hline Phosphate & - & $\mathrm{mg} / 1$ \\
\hline Silica & Not exceed than 0.01 & $\mathrm{mg} / 1$ \\
\hline Cadmium $(\mathrm{Cd})$ & Not exceed than 0.01 & $\mathrm{mg} / 1$ \\
\hline Iron $(\mathrm{Fe})$ & Not exceed than 1.0 & $\mathrm{mg} / 1$ \\
\hline Nickel $(\mathrm{Ni})$ & Not exceed than 0.2 & $\mathrm{mg} / 1$ \\
\hline Lead $(\mathrm{Pb})$ & Not exceed than 0.05 & $\mathrm{mg} / 1$ \\
\hline
\end{tabular}

Temperature: Water temperature is very important, as many of the physical, biological, and chemical characteristics of aquatic ecosystem are directly affected by temperature [20]. the recorded values ranged from 13.10 to $33.50{ }^{\circ} \mathrm{C}$ with an average of $24.23 \pm 5.84$. The variation is associated with sampling time as shown in (Figure 2). The maximum value was recorded in station $\mathrm{X}$ in August, while the lowest was detected in January at station I. The decrease or increase in surface water temperature depends on different factors as seasonal variation, climatic conditions, in addition to the specific characteristics of water environment such as turbidity, wind force and humidity [21].

Table 3: Summary of basic descriptive statistics (units in mg/l except Temp.,Turb.,pH, and EC).

\begin{tabular}{l|l|l|l|l}
\hline Parameter & Mean & Std & Min & Max. \\
\hline Temp. ${ }^{\circ} \mathrm{C}$ & 24.23 & 5.84 & 13.10 & 33.50 \\
\hline Turb. NTU & 6.35 & 1.30 & 3.80 & 11.20 \\
\hline $\mathrm{pH}$ & 8.09 & .44 & 5.49 & 8.91 \\
\hline TDS & 223.52 & 45.24 & 152 & 365 \\
\hline E.C $\mu$ s/cm $]$ & 419.80 & 66.09 & 315 & 624 \\
\hline DO & 6.95 & 1.71 & 2.31 & 11.20 \\
\hline BOD & 5.09 & 2.27 & 1.90 & 12.55 \\
\hline chlorides & 37.20 & 4.84 & 20 & 48 \\
\hline Alkalinity & 145.81 & 16.85 & 120 & 192 \\
\hline T.Hardness & 178.25 & 16.33 & 140 & 228 \\
\hline Ca Hardness & 98.44 & 10.58 & 80 & 136 \\
\hline Mg.Hardness & 79.86 & 12.18 & 48 & 108 \\
\hline Ammonia & 0.14 & .016 & 0.02 & .66 \\
\hline Nitrite & 0.05 & .047 & 0.002 & .28 \\
\hline Nitrate & 1.74 & 2.13 & 0.005 & 2.34 \\
\hline Phosphate & 0.8 & .025 & 0.002 & 2.04 \\
\hline Silica & 1.02 & .58 & 0.04 & 3.20 \\
\hline Cadmium & .02 & .09 & 0.001 & 1.011 \\
\hline Iron & .06 & .11 & 0.01 & 1.033 \\
\hline Nickel & .04 & .03 & 0.003 & .304 \\
\hline Lead & .03 & .01 & 0.001 & .095 \\
\hline & & & &
\end{tabular}

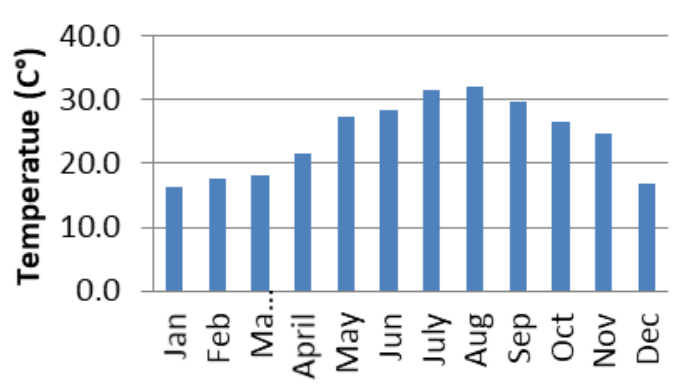

Figure 2: Monthly annual average values of surface water temperature of the study area.

Turbidity: Turbidity of water samples ranged from 3.80 to 11.20 NTU with an average of 
$6.35 \pm 1.30 \mathrm{NTU}$. This indicates that the water turbidity in the study area was within the permissible limit of the EESR. Station X, was the lowest, while station III had the highest turbid location followed by station IV. Other stations (V, VI, VII and VIII) showed closed turbidity values (Figure 3).Turbidity depends on total solids which suspended in surface water [22] As turbidity increases, it reduces the clarity of water to transmitted light by causing light to be scattered and adsorbed and act as quick indicator for decreasing in water quality, not just potential pollution [23].

pH: It is a vital indicator for surface water quality and pollution extent [24]. The study area was slightly alkaline. The $\mathrm{pH}$ values ranged from 5.49 to 8.91 with an average of $8.09 \pm 0.443$ (Table 3) The $\mathrm{pH}$ values were recorded slightly above the permissible limit of the EESR (Table 2 ). This indicate the presence of calcium and magnesium carbonates in fresh surface water [25]. Spatially, station III was recorded the highest annual average of $8.40 \pm 0.48$, while the lowest was recorded at station $\mathrm{X}$ with average of 8.04 \pm 0.21 (Figure 3).

Total dissolved solids: In all measured samples, TDS values did not exceed $365 \mathrm{mg} / \mathrm{l}$. According to the EESR, TDS value must be below $500 \mathrm{mg} / \mathrm{l}$ (Table 2). In the current investigation, the obtained values were ranged between 152-365 mg/l with an annual average of $223.5 \pm 45.24 \mathrm{mg} / \mathrm{l}$ (Table 3). Spatially, station $\mathrm{X}$ was recorded the highest, while, the lowest annual average appeared at station VIII (Figure3). Low TDS values may be related to elevation rate of water drainage from rain precipitation in addition to the weak rate of water evaporation [26].

Electrical conductivity: EC values ranged from 315 to $624 \mu \mathrm{S} / \mathrm{cm}$ with a mean value of $419.80 \pm 66.09 \mu \mathrm{S} / \mathrm{cm}$ (Table 3) The highest EC value was $442 \mu \mathrm{S} / \mathrm{cm}$ at station $X$ followed by station II $(426 \mu \mathrm{S} / \mathrm{cm})$, while the lowest annual average was $410 \mu \mathrm{S} / \mathrm{cm}$ at station VII (Figure 3 ). It is a measure of the ability of water to pass an electrical current.[27]. It is affected by the presence of inorganic dissolved solids which sensitive to the variations of total dissolved solids [28].

Dissolved oxygen: Values of DO ranged between 2.31 and $11.20 \mathrm{mgO}_{2} / \mathrm{l}$, with an annual average of $6.95 \pm 1.71 \quad \mathrm{mgO}_{2} / \mathrm{l}$ (Table 3). Spatially, the highest annual average value appeared at station $\mathrm{X}$ while, the lowest value was recorded at station III. Most of sampling stations are ranged between 6.95 and $8.1 \mathrm{mg} / \mathrm{l}$ as shown in (Figure 3). DO is a crucial indicator to sustain aquatic life and reflects the health and quality status of any aquatic ecosystem. Regions with high values of DO reflected a better water quality [29].

Biochemical oxygen demand: The values ranged from 1.90 to $12.55 \mathrm{mg} / \mathrm{l}$ with an average value of $5.09 \pm 2.27 \mathrm{mg} / \mathrm{l}$ (Table 3). Spatially, the highest value was at station III with an annual average of $8.71 \mathrm{mg} / \mathrm{l}$, while stations (VIII \& X) recorded the lowest values respectively $(3.63 \&$ 3.46) $\mathrm{mg} / \mathrm{l}$ (Figure 3). Temporally, elevated ranges appeared at spring and summer; the highest mean value was recorded in May with an average of $6.31 \mathrm{mg} / \mathrm{l}$, while the lowest mean values were noted in October with an average of $3.69 \mathrm{mg} / \mathrm{l}$. When organic matter in water is decomposed by aerobic germs, the oxygen absorbed biologically increased. High (BOD) values reflect high levels of organic matter in water, which adversely affect the water quality and act as an important indicator for pollution that reflects the load of organic wastes. [30].

Chloride: In current study the lowest concentration of chlorides was $20 \mathrm{mg} / \mathrm{l}$, while maximum concentration was $48 \mathrm{mg} / \mathrm{l}$ with annual average of $37.20 \pm 4.84 \mathrm{mg} / \mathrm{l}$. Chlorides values were provided information on physical processes especially evaporation occurring during recharge and time-dependent flow [31].

Alkalinity: In this study, alkalinity values were in the range of 120 to $192 \mathrm{mg} / \mathrm{l}$ with an average of $145.81 \pm 16.85 \mathrm{mg} / \mathrm{l}$. Most of values were above the permissible limits of EESR (Table 2). Spatially, stations (V\&I) recorded the highest values while, station IX was recorded the lowest annual average value of $140.83 \pm 19.95 \mathrm{mg} / \mathrm{l}$. It is not a chemical description of water but it is a property of water that is dependent on the presence of certain chemicals in the water, such as bicarbonates, carbonates and hydroxides [12].

Ammonia: The average concentration of ammonia during the study period was $0.14 \pm 0.016 \mathrm{mg} / \mathrm{l}$ with peak value of $0.66 \mathrm{mg} / \mathrm{l}$ obtained at station III. the lowest value was observed at station I $(0.024 \mathrm{mg} / \mathrm{l})$. According to EESR, the permissible limit of ammonia in the surface water body must be below $0.5 \mathrm{mg} / \mathrm{l}$. In the present study, most of ammonia values were under presumable limits of EESR as shown in (Table 2). It is mostly produced by decomposition of organic matter in addition to hydrolysis of urea from dead fish in water [32]. 
Nitrite: EESR not determine the permissible limits of nitrite in fresh surface water body of the Nile. As shown in (Table 2). The results showed that nitrite concentrations were ranged between $0.002-0.29 \mathrm{mg} / \mathrm{l}$ with an average of $0.05 \pm 0.04 \mathrm{mg} / \mathrm{l}$ (Table 3 ). Nitrite is not stable and its appearance in higher concentrations generally indicates that changes are in progress (nitrification processes) [33].

Nitrate: In this study, the nitrate values ranged between 0.005 and $2.34 \mathrm{mg} / \mathrm{l}$ (Table 3) According to EESR, the permissible limit of nitrate must be not exceeded that of $45 \mathrm{mg} / \mathrm{l}$ in the fresh water bodies. The maximum value of nitrate was under the permissible limits. Spatially, station III was recorded the highest average $3.32 \pm 1.44 \mathrm{mg} / \mathrm{l}$ while station $\mathrm{X}$ showed the lowest value with $0.87 \pm 0.076 \mathrm{mg} / \mathrm{l}$ (Figure 3 ). The increasing values relative to presence of agricultural and industrial drainage in this station which receive sewage and waste.

Phosphates: values were ranged between 0.002 and $2.04 \mathrm{mg} / \mathrm{l}$ Station II, was recorded the highest value, while station $\mathrm{X}$ was the lowest with average of $0.024 \pm 0.01 \mathrm{mg} / \mathrm{l}$. The permissible limit of phosphate is absent from EESR guidelines (Table 2). In general, major sources of phosphate in surface water are domestic sewage, agriculture effluents and industrial wastewaters.[34]

Silica concentrations: Silicates ranged from 0.046 to $3.20 \mathrm{mg} / \mathrm{l}$ with an average value of $1.04 \pm 0.58 \mathrm{mg} / \mathrm{l}$ (Table 3). Spatially, station III showed the highest value with $0.72 \pm 0.2 \mathrm{mg} / \mathrm{l}$, whilst station IX appeared the lowest with $0.7 \pm 0.46 \mathrm{mg} / \mathrm{l}$ (Figure 3) According to EESR this averaged value was higher than the permissible limit which should not exceed 0.01 $\mathrm{mg} / \mathrm{l}$. The results revealed the richness in silicates at the study area with extreme discrimination between the concentrations on spatial scales. The elevation due to easy solubility of silica in river by the weathering of rocks and mineral in the catchments area.[35].

\section{Heavy Metals}

The intensive human activities, natural sources and effluent discharges are the main sources of heavy metal pollution in surface water. Heavy metals altered into more toxic form or remain unchanged which more stable and less toxic [36]. In this study, four metals were selected. Unlike other pollutants, dissolved heavy metals can be biodegraded and destroyed completely, metals are not biodegradable and can neither be created nor destroyed [37].

Nickel: EESR stated that concentrations of dissolved nickel in surface water must not exceed $0.2 \mathrm{mg} / \mathrm{l}$. In the current study, nickel concentrations ranged between 0.003 and 0.30 $\mathrm{mg} / \mathrm{l}$ with an average of $0.04 \pm 0.03 \mathrm{mg} / \mathrm{l}$. Station IV appeared the highest value while station IX recorded the lowest concentrations.

Cadmium: According to EESR, concentration of cadmium in surface water must not exceed $0.01 \mathrm{mg} / \mathrm{l}$. In this study, the concentrations ranged between 0.001 and $1.01 \mathrm{mg} / \mathrm{l}$ with an average of $0.02 \pm 0.09 \mathrm{mg} / \mathrm{l}$ (Table 3). The obtained results showed that cadmium content was slightly above the permissible limit of $0.01 \mathrm{mg} / \mathrm{l}$. Spatially the highest annual average was more than $0.010 \mathrm{mg} / \mathrm{l}$. and recorded at station IV, other stations were below $0.02 \mathrm{mg} / \mathrm{l}$. The lowest annual average along the study period was recorded at station I with a $n$ average of $0.005 \pm 0.004 \mathrm{mg} / \mathrm{l}$ in general, a high proportional of cadmium is usually associated with organic matter [38].

Iron: The lowest recorded value of iron concentration was $0.01 \mathrm{mg} / \mathrm{l}$ while, the maximum value was $1.03 \mathrm{mg} / \mathrm{l}$. Although EESR stated that the concentrations of iron in the surface water must not exceed $1.0 \mathrm{mg} / \mathrm{l}$. Some reported results of this study were higher than permissible limit. Spatially, station III was the highest value with $0.20 \pm 0.31 \mathrm{mg} / \mathrm{l}$, while the lowest value was recorded in station VIII $0.03 \pm 0.02 \mathrm{mg} / \mathrm{l}$

Lead: The permissible limit of lead concentrations in EESR must not exceed that of $0.05 \mathrm{mg} / \mathrm{l}$ as showed in (Table 2). Values of lead concentration ranged from 0.001 to $0.095 \mathrm{mg} / \mathrm{l}$ with an average of $0.03 \pm 0.01 \mathrm{mg} / \mathrm{l}$. In the current investigation, lead values were within the permissible limit. Spatially, station I recorded the lowest concentration of that $0.02 \pm 0.009 \mathrm{mg} / \mathrm{l}$. Station IV and Station III recorded the highest values corresponding to $0.04 \pm .02$ and $0.04 \pm 0.01 \mathrm{mg} / \mathrm{l}$ respectively. These stations may be exposed to heavy domestic sewage and/or agricultural runoffs.

\section{Correlation Coefficients for Water Parameters}

Correlations (Pearson's product moment) between pairs of water quality parameters were calculated for data interpretation (Table 6). Positive Significant correlations between pairs of water quality parameters mean proportional 
relationships. However, negative significant correlations reflect interlocking and counteraction between the measured parameters; one variable tends to decrease as the other increases.

Temperature was the most significant factor among other physicochemical parameters. There was a positive significant correlation between temperature and silica $(r=0.209)$, BOD $(r=0.195)$ and $\mathrm{pH}(\mathrm{r}=0.290)$. Although, temperature had a negative significant relation with alkalinity ( $r=-0.198)$. TDS $(r=-0.523)$, EC $(r=-0.310)$, DO $(r=-0.408)$, total hardness $(r=-0.459)$, and with calcium \& magnesium hardness $(r=-0.340),(r=-0.325)$ respectively. Turbidity was showed a medium significant positive correlation with $\mathrm{pH}(r=0.196)$, nitrate $(r=0.183)$, silica $(r=0.207)$, lead $(r=0.195)$. The strong significant $(r=0.391)$ with BOD. It might be due to the colloidal behavior of lead with suspended matter. A negative significant correlation recorded between turbidity and both of DO and calcium hardness $(r=-0.182)$ and $(r$ $=-0.183$ ) respectively.

A significant positive correlation was found between $\mathrm{pH}$ and silica $(\mathrm{r}=0.244)$, while $\mathrm{pH}$ had a significant negative correlation between both of TDS and DO $(r=-0.192),(r=-0.272)$ respectively

Total dissolved solids had a significant positive correlation normally with Electrical conductivity $(r=0.717)$. Increasing of TDS was observed between some water quality parameters including DO $(r=0.405)$, total. hardness $(r=0.378)$; and magnesium hardness $(r=0.380)$. The higher values of TDS were attributed to the higher rate of material dissolved in a water or found in sediments [35] Electrical conductivity had a positive significant correlation with 4 parameters; with DO $(r=0.196)$, alkalinity $(r=0.468)$, total. hardness $(r=0.348)$, magnesium hardness $(r=$ $0.426)$. While, negatively with nitrate $(r=-$ 0.266), which indicated the decreasing the nitrate content Alkalinity has significant correlation with TDS $(r=0.225)$ which supporting the observation of high concentrations of these parameters at Damietta. Total hardness showed positive correlation with alkalinity $(r=0.294)$, magnesium hardness $(r$ $=0.363)$ and phosphate $(r=0.199$, ) that reflect the positive significant correlation between alkalinity and these parameters. Total. hardness had a significant positive correlation with both Calcium hardness $(r=0.670)$ and magnesium hardness $(r=0.763)$ which ensured that hardness of both $\left(\mathrm{Mg}^{+2}, \mathrm{Ca}^{+2}\right)$ were the major contributor of total hardness.[16]. The increasing of surface water $\mathrm{pH}$, the increasing in calcium content Ammonia and heavy metals including cadmium $(r=0.181)$, and with nickel and iron $(r=0.340)$ by the same value, silica and iron $(r=0.189)$. and between Nickel with cadmium $(r=0.356)$ and iron $(r=0.456)$, BOD with nitrate $(r=0.189)$ and silica $(r=0.203)$. In aerobic conditions, nitrogenous compounds are biologically oxidized to ammonium, nitrites and nitrates minimizing the dissolved oxygen content in the aquatic environment. While negatively significant with DO $(r=-0.235)$, silica $(r=-0.224)$ and iron $(r=-0.190)$. However, DO was positively with Total Hardness $(r=0.255)$, Ca. Hardness $(r=0.231)$ and E.C ( $r=0.196)$ supporting the fact that the concentrations of dissolved oxygen decrease with increasing BOD $[7,12]$.

\section{Water Quality Index (WQI)}

Monthly WQI value was calculated for each sampling site which give an overview for the quality of water body. Many remarkable features were showed the water quality status of river. Spatial description of water quality according to the calculated WQI showed a medium condition at most locations. Obtained results of calculated WQI had been expressed in good, medium and bad. Classification of water related to the calculated WQI. and Pollution Degree of water quality and its classification corresponding to WQI referring water class as shown in (Table 6) According to the calculated values of WQI, the sampling stations can be ranked in a descending order from the best to the worst station as follow: St.IX(66.70)> St.X(66.40)> St.VIII(65.35)> St.V(63.95)> St.VII(63.87) > St.I (62.55) > St.VI (62.52)> St.II(61.33)> St.IV(58.89) > St.III(56.44) (Figure 4). All of the previous values were a reflection of water quality levels indicated medium quality of surface water of Damietta branch the Nile river at Damietta region. 

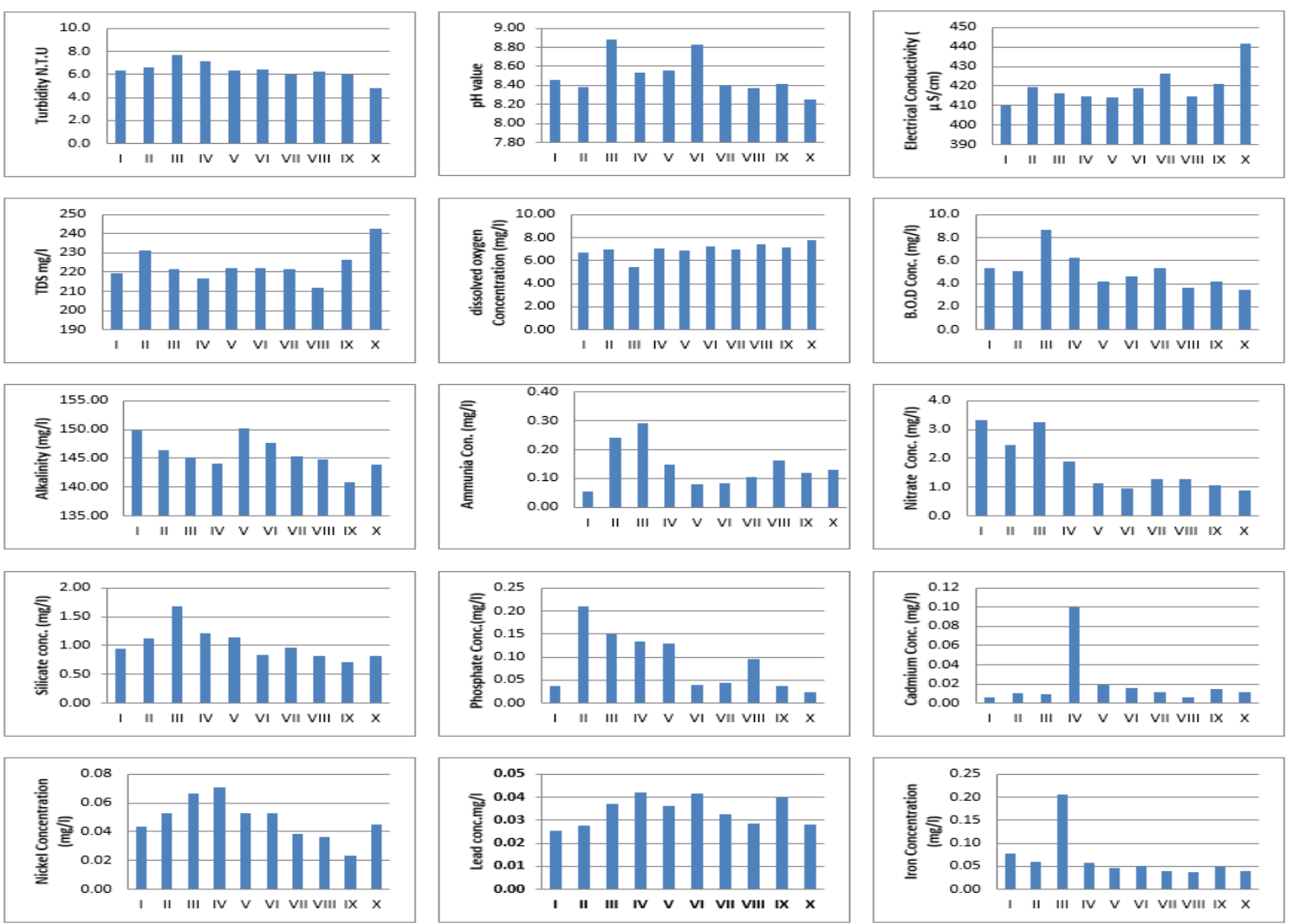

Figure 3: Spatial annual average values of some surface water parameters at Damietta, during the period from January to December, 2014

Table 4: classes of water related to values range of the calculated WQI. and Pollution Degree of water quality and its classification corresponding to WQI referring water class (Srivastava et al,2013).

\begin{tabular}{c|c|c|c}
\hline Status & $\begin{array}{c}\text { WQI } \\
\text { range }\end{array}$ & Class & QualityDegree \\
\hline Excellent & $91-100$ & $\mathrm{~A}$ & Permissible range \\
\hline Good & $71-90$ & $\mathrm{~B}$ & $\begin{array}{c}\text { Slight to permissible } \\
\text { range }\end{array}$ \\
\hline Medium & $51-70$ & $\mathrm{C}$ & $\begin{array}{c}\text { Moderate to slight } \\
\text { range }\end{array}$ \\
\hline Bad/poor & $26-50$ & $\mathrm{D}$ & $\begin{array}{c}\text { Severe to moderate } \\
\text { range }\end{array}$ \\
\hline very bad & $0-25$ & $\mathrm{E}$ & $\begin{array}{c}\text { Severe to moderate } \\
\text { range }\end{array}$ \\
\hline
\end{tabular}

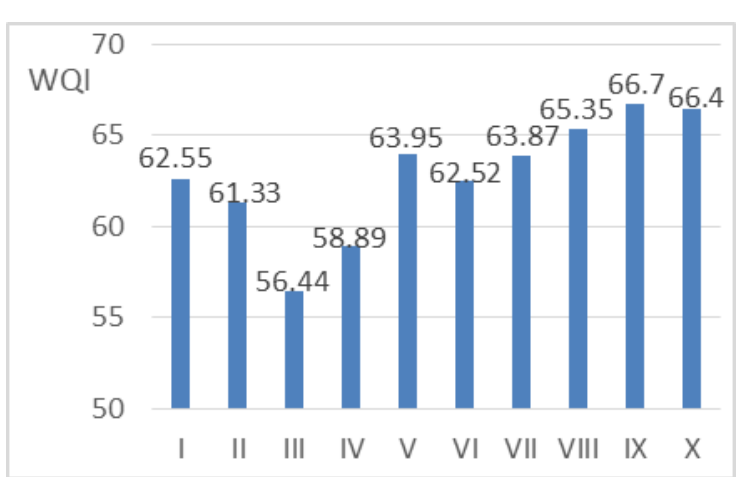

Figure 4: the calculated values of water quality index at sampling stations

Table 5: Spatial and monthly calculated WQI values for surface water during, 2014

\begin{tabular}{l|l|l|l|l|l|l|l|l|l|l}
\hline \begin{tabular}{l} 
Month/ \\
\multicolumn{1}{c|}{ Station }
\end{tabular} & St.I & St.II & St.III & St.IV & St.V & St.VI & St.VII & $\begin{array}{l}\text { St.VII } \\
\text { I }\end{array}$ & St.IX & St.X \\
\hline Jan. & 61.44 & 59.45 & 49.11 & 57.43 & 63.93 & 53.04 & 60.31 & 71.51 & 48.43 & 63.6 \\
\hline Feb. & 60.38 & 62.14 & 61.65 & 53.73 & 54.37 & 73.07 & 60.79 & 60.78 & 69.11 & 59.49 \\
\hline Mar. & 66.63 & 54.25 & 55.73 & 57.48 & 66.22 & 59.75 & 65.16 & 63.18 & 65.19 & 61.67 \\
\hline April & 67.36 & 56.87 & 56.98 & 50.96 & 63.65 & 59.63 & 63.18 & 66.23 & 65.13 & 74.59 \\
\hline May & 60.27 & 60.86 & 57.57 & 54.42 & 69.82 & 62.38 & 71.53 & 59.6 & 73.41 & 64.29 \\
\hline June & 69.04 & 69.29 & 58.79 & 54.18 & 59.38 & 69.8 & 60.45 & 64.41 & 72.63 & 72.89 \\
\hline July & 58.96 & 58.53 & 58.53 & 51.18 & 60.38 & 47.33 & 53.38 & 61.52 & 61.47 & 58.61 \\
\hline Aug. & 51.13 & 51.57 & 50.84 & 54.87 & 57.53 & 59.28 & 59.13 & 57.86 & 59.52 & 60.17 \\
\hline Sep. & 67.60 & 63.99 & 64.63 & 67.84 & 65.74 & 65.33 & 69.66 & 65.74 & 71.19 & 71.68 \\
\hline Oct. & 64.42 & 66.74 & 61.79 & 71.18 & 63.69 & 66.36 & 71.42 & 71.23 & 74.69 & 64.69 \\
\hline Nov. & 64.42 & 66.74 & 61.79 & 66.78 & 63.69 & 66.36 & 61.42 & 68.23 & 71.49 & 64.69 \\
\hline Dec. & 59.42 & 63.23 & 42.97 & 64.59 & 72.87 & 68.8 & 66.59 & 71.47 & 71.37 & 73.65 \\
\hline WQI average & 62.55 & 61.33 & 56.44 & 58.89 & 63.95 & 62.52 & 63.87 & 65.35 & 66.70 & 66.40 \\
\hline
\end{tabular}


Table 6: Pearson's correlation coefficient between physico-chemical variables for collected samples in Damietta region during (January / December), 2014*correlation is significant at $\mathrm{p}<0.05$ level ; ** correlation is significant at $\mathrm{p}<0.01$ level

\begin{tabular}{|c|c|c|c|c|c|c|c|c|c|c|c|c|c|c|c|c|c|c|c|c|c|}
\hline & \begin{tabular}{|l} 
Temp. \\
\end{tabular} & Turb. & pH & TDS & $\overline{E C}$ & DO & BOD & $\mathrm{Cr}$ & Alk. & T.H & Ca.H & \begin{tabular}{|l|} 
Mg.H \\
\end{tabular} & Amm & $\mathrm{NO}_{2}{ }^{-}$ & $\mathrm{NO}_{3}{ }^{-}$ & $\mathrm{PO}_{4}^{-3}$ & Si & Cad. & Iron & $\mathrm{Ni}$ & $\mathbf{P b}$ \\
\hline $\begin{array}{l}\text { Temp. } \\
\text { Turb. }\end{array}$ & $\begin{array}{c}1 \\
.082\end{array}$ & & & & & & & & & & & & & & & & & & & & \\
\hline pH & $.290^{* *}$ & $.196^{*}$ & 1 & & & & & & & & & & & & & & & & & & \\
\hline TDS & $-.523^{* *}$ & .032 & $-.192-^{*}$ & 1 & & & & & & & & & & & & & & & & & \\
\hline EC & $-.310^{* *}$ & .035 & -.041 & $.717^{* *}$ & 1 & & & & & & & & & & & & & & & & \\
\hline DO & $-.4088^{-* *}$ & $-.182-^{*}$ & $-.2722^{* *}$ & $.405^{* *}$ & $.196^{*}$ & 1 & & & & & & & & & & & & & & & \\
\hline BOD & $.195^{*}$ & $.391^{* *}$ & .161 & -.108 & -.093 & $-.235-^{* *}$ & 1 & & & & & & & & & & & & & & \\
\hline $\mathrm{Cl}^{-}$ & -.115 & -.090 & -.018 & -.052 & -.063 & .044 & -.050 & 1 & & & & & & & & & & & & & \\
\hline Alk. & -..198-* & .090 & .097 & $.225^{*}$ & $.468^{* *}$ & -.042 & -.065 & -.115 & 1 & & & & & & & & & & & & \\
\hline T.H & $-.4599^{* * *}$ & -.120 & -.157 & $.378^{* *}$ & $.348^{* *}$ & $.255^{* *}$ & -.128 & -.076 & $.294^{* *}$ & 1 & & & & & & & & & & & \\
\hline Ca.H & $-.3400^{* *}$ & $-.183-*$ & -.138 & .154 & .048 & $.231^{*}$ & -.153 & .059 & .034 & $.670^{* *}$ & 1 & & & & & & & & & & \\
\hline Mg.H & $-.325^{* * *}$ & -.005 & -.094 & $.380^{* *}$ & $.426^{* *}$ & .149 & -.038 & -.156 & $.363^{* *}$ & $.763^{* *}$ & .033 & 1 & & & & & & & & & \\
\hline Amm & -.070 & .111 & .161 & -.069 & -.100 & -.032 & .124 & .010 & -.031 & .017 & .106 & -.073 & 1 & & & & & & & & \\
\hline $\mathrm{NO}_{2}^{-}$ & .110 & .142 & .007 & -.079 & .085 & .092 & .066 & -.060 & .095 & .119 & .077 & .089 & .077 & 1 & & & & & & & \\
\hline $\mathrm{NO}_{3}{ }^{\circ}$ & -.053 & $.183^{*}$ & .043 & -.098 & $-.2666^{* *}$ & .008 & $.189^{*}$ & -.006 & -.082 & .006 & .001 & .009 & .156 & -.067 & 1 & & & & & & \\
\hline $\mathrm{PO}_{4}^{-3}$ & .087 & .148 & -.008 & .146 & .114 & -.171 & .018 & -.044 & $.199^{*}$ & -.031 & -.095 & .040 & -.133 & -.109 & -.074 & 1 & & & & & \\
\hline $\mathrm{Si}$ & & $.207^{*}$ & $.244^{* *}$ & -.085 & .032 & $-.224-^{*}$ & $.203^{*}$ & -.012 & .140 & .081 & -.028 & .130 & .134 & .143 & .143 & .175 & 1 & & & & \\
\hline Cad. & -.092 & .063 & -.037 & .106 & -.001 & .146 & .026 & .118 & .077 & .070 & -.039 & .126 & $.181^{*}$ & .030 & .092 & .004 & -.026 & 1 & & & \\
\hline Iron & -.086 & .019 & -.069 & -.041 & -.172 & $-.190-^{*}$ & .177 & -.020 & -.098 & .022 & .108 & -.065 & $.340^{* *}$ & -.072 & .132 & -.045 & $.189^{*}$ & -.030 & 1 & & \\
\hline $\mathrm{Ni}$ & -.109 & .094 & -.057 & .064 & -.046 & -.171 & .076 & -.049 & .029 & .011 & .058 & -.036 & $.340^{* *}$ & -.044 & .148 & -.138 & -.060 & $.356^{* *}$ & $.456^{* *}$ & 1 & \\
\hline $\mathbf{P b}$ & .145 & $.195^{*}$ & .083 & .008 & .002 & .018 & .064 & -.010 & -.072 & -.066 & -.134 & .025 & -.041 & .085 & -.081 & -.017 & .098 & .096 & -.155 & .043 & 1 \\
\hline
\end{tabular}
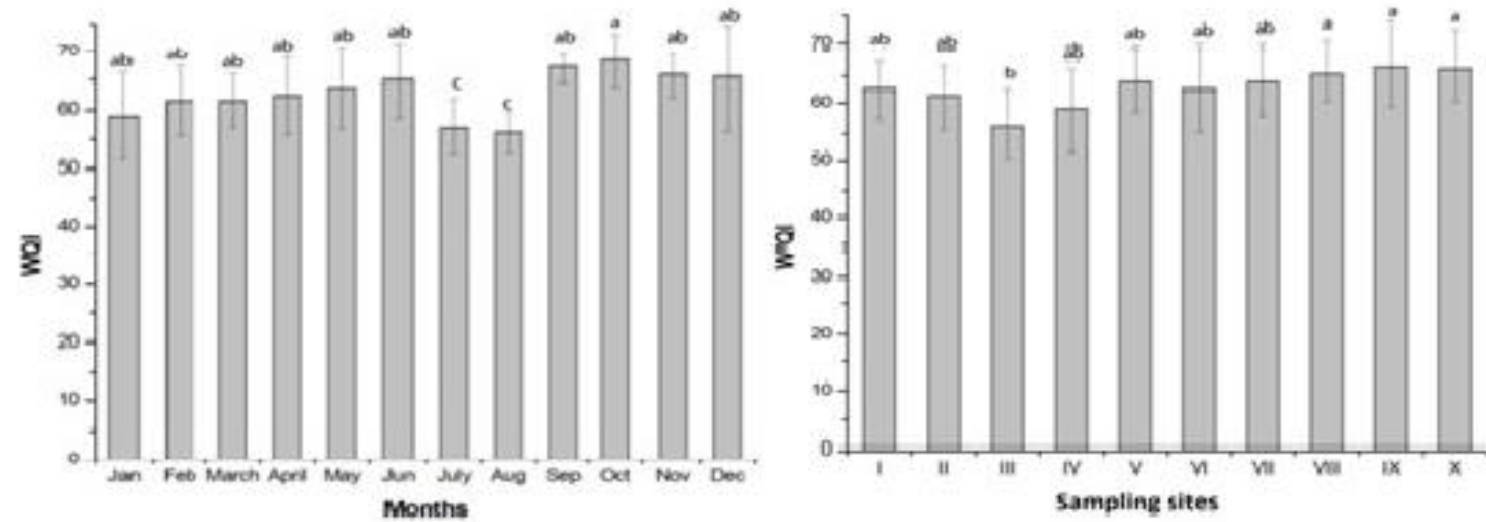

Figure 5: Temporal and Spatial variation of WQI at Damietta during, 2014.Using One-way ANOVA with Tuckey's b test the values of error bars ( $\mathrm{Sd}$, the asterisks indicate significant differences)

It was noted that non of the sampling stations during the entire study period had WQI value equals or close to 100 implies a good water condition. The obtained results of WQI values proofed that the river east bank was better than that of the western side. The absolute maximum WQI was calculated at station VII (75.53\%), while the absolute minimum value was appeared at station III (42.97\%) (Table 5) Temporally, the study area is classified severe to moderate range of pollution Only $14 \%$ of all calculated values ranged between $71-90 \%$ in WQI reflecting a good water quality within the class B with degree of slight to permissible range in pollution degree (Table $4 \& 5$ ).Most of calculated values (more than $82 \%$ ) were ranged between $51 \%$ and $70 \%$ in WQI reflecting a medium quality and classified as class $\mathrm{C}$ with degree of Moderate to slight range in pollution degree. (Table 4\&5). The calculated values of WQI for most sampling station reflected a medium status which agreed with the previous studies that carried out at Damietta region $[7,12,16]$.Generally, the similarity of over-all results obtained indicated medium status for most stations except the increasing of pollution load at station III, where the results were showed moderate to slight range of pollution and the WQI varied between 49.11 and $64.63 \%$ with an average of that $56.44 \pm 6.07 \%$. The minimum value appeared during December, the low values of WQI may be due to the occasional mixing of effluent discharged by the hot water outlet of hydropower and occasional mixing of effluent discharged by drain or village or waste water from village.

According to Figure 5, the One-way ANOVA with Tuckey's b test around the year was divided into 3 groups; (a) referred to the highest WQI values which appeared in October. While, the lowest values represented by (c) appeared in July and August which may be attributed to increasing of organic matter during summer months. Other months were considered in a moderate quality status. Spatially, the stations 
were divided into 3 groups ;(a) included stations (VIII, IX and X) with the highest values of WQI which indicated the best quality. On the other hand, the group (b) included only station III which had the lowest value of WQI and referred bad quality. The rest stations were considered in a moderate quality status and labelled (ab). The acceptable level of water quality should be ranged between medium or good of WQI values $[22,26]$. This reflect the importance of using WQI for monitoring and screening can give a significant indicator for water quality and keep tracks of any changes overtime. Therefore, provide a simple and understandable device on the quality and possible uses of given water body.

\section{Conclusion}

In this current study, we use the results of some estimated physicochemical parameters in surface water samples in Damietta branch of the Nile river at Damietta district, Egypt.

WQI was calculated from certain selected parameters to evaluate the quality status of this part in the ecosystem. Using WQI tool, it become easy to convert a vast large amount of information and reduces results to give a single mathematical number for assessment the water condition as quick indicator for water quality health. subsequently, ranking water body into one of 5 pollution degree based on WQI value. Accordingly, the water quality status varied between good to medium or bad. The obtained results showed that the surface water of this part of river Eastern bank is better than that of Western bank. WQI varied between 49.11 and $64.63 \%$ with an average of that $56.44 \pm 6.07 \%$. Generally, the quality status of all location found in medium condition except station III based on the WQI annual average value. However, the mean values of most measured parameters were within the threshold limits in comparison for the EESR. We recommended the necessity of the continuous and regular monitoring of any ecosystem and follow up its status at a period of time. It is important to maintain pollution levels within the permissible values. Environmental quality control should be enforced to prevent or decrease the entrance of wastewater from agricultural, domestic, industrial, or other sources to the Nile River system.

\section{Acknowledgment}

Deep appreciation to all those who provided us the possibility to complete this research. Also, thank the helpful support for all staff members at zoology Dept., Fac. of Sci., Damietta Uni. and my colleague in Central Laboratory of Damietta Water Company for providing the equipment and research facilities.

\section{Reference}

Mohamed, I., Othman, F., Ibrahim, A.I., Alaa-Eldin, M., and Yunus, R.M. (2015). Assessment of water quality parameters using multivariate analysis for Klang River basin, Malaysia. Environmental monitoring and Assessment.;187(1):1-12.

Abdel-Satar A.M. (2005). Water Quality Assessment of River Nile From Idfo to Cairo. Egyptian Journal of Aquatic Research:16874285 ;31 (2): 200-223.

Khalifa N. and Sabae S.Z. (2012). Investigation on mutual relations between bacteria and zooplankton in Damietta branch, River Nile, Egypt. Journal of Applied Sciences Research; 8(5):2679-2688.

Jubek, D.S.K.; Bin,X. and Loro, E. L. L. (2019). Impact of climate change on water in South Sudan. International Journal of Scientific and Research Publications (IJSRP); 9(1):8516.

Mostafa, M. E. and Abdelazim, M. N. (2017). Impact of Water Quality on Ecosystems of the Nile River. Handbook Environ. Chemistry, Springer International Publishing, 2(55):741.

Wang, N. and Choi, Y. (2019). Challenges for Sustainable Water Use in the Urban Industry of Korea Based on the Global Non-Radial Directional Distance Function Model. Sustainability, 11(14): 3895.

Hasaballah, A.F. Hegazy T.A., Ibrahim M. S. and ElEmam D.A. (2019). Assessment of Water and Sediment Quality of the River Nile, Damietta Branch, Egypt. Egyptian Journal of Aquatic Biology \& Fisheries;23(5): 55- 65.

Kegley, E.S. and Andrew, J. (1998). The Chemistry of Water. Chemical Parameters for Water Quality (2nd edition.) California: University Science Books. pp: 13-162.

Golteman, H. L. (1978). Methods for Physical and Chemical Analysis of Fresh Waters. USA: Billing and Sons Ltd.

El-Tohamy, W.S., Abdel-Baki, S.N., Abdel-Aziz, N.E. Abdel-Aziz A. Khidr (2018). Evaluation of Spatial and Temporal Variations of Surface Water Quality in the Nile River Damietta 
Branch. Ecological Chemistry and Engineering: 25(4), 569-580.

El-Ezaby, KH., EL-Sonbati M. A. and Badr.E. A. (2010). Impact of fish cages on the Nile water quality at Damietta Branch. Mansoura Journal of Environmental Sciences. 39 (3): 329-344.

Badr S. A., Mervat A. El-Sonbati and Hossam M. Nassef (2013). Water Quality Assessment in the Nile River, Damietta Branch, Egypt, The Egyptian Society for Environmental Sciences. 8 (1): 41-50.

APHA, (1998). Standard Methods for the Examination of Water and Wastewater. 20th edition. American Public Health Association (APHA), American Water Works Association (AWWA) \& Water Environment Federation (WEF), Washington D.C., USA.

APHA (2005). Standard Methods for the Examination of Water and Wastewater. 21st Edition. American Public Health Association (APHA), American Water Works Association (AWWA) \& Water Environment Federation (WEF), Washington D.C., U.S.A.

Yasser, A. E.; Mahmoud, A. Z. and Sadam, H. A. (2015). Assessment of the Physico-Chemical Characteristics of Water and Sediment in Rosetta Branch, Egypt. Journal of Water Resource and Protection. 7: 1075-1086.

Hiren B.S. \& Sheju Thomas. (2013). Assessment of Surface Water Quality in Relation to Water Quality Index of Tropical Lentic Environment, Central Gujarat, India. International Journal of Environment:2091-28543(1) 168:178.

Garima S. \& Pradeep K. (2013). Water Quality Index with Missing Parameters. International Journal of Research in Engineering and Technology:2319-1163(2) 04: 609:614.

Pesce, S.F. \& Wunderlin, D.A. (2000). Use of water quality indices to verify the impact of Cordoba City (Argentina) on Suquia River. Water Research, 34 (11): 2915-2926.

Sanchez, E., Colmenarejo, M.F., Vicente, J., Rubio, A., Garcia, M.G., Travieso, L. And Borja, R. (2007). Use of the water quality index and dissolved oxygen deficit as simple indicators of water sheds pollution. Ecological Indicators 7 (2): $315-328$.

Delince, G. (1992): The ecology of the fish pond ecosystem with special reference to Africa. Text book, Kluwer Academic Publishers, 230 pp.

Mahmoud, S.A., 2002. Evaluation of toxicity of some pollutant on histological and biochemical features of Orcachomis niloticus in River Nile. Ph.D. Thesis, Faculty of Science, Banha Branch, Zagazig University, Egypt.

Aniyikaiye, T. E.; Oluseyi, T.; Odiyo, J. O. and Edokpayi, J. N. (2019). PhysicoChemical
Analysis of Wastewater Discharge from Selected Paint Industries in Lagos, Nigeria. Int. J. Environ. Res. Public Health, 16:1235.

Wood, M. S. (2014). Estimating suspended sediment in rivers using acoustic Doppler meters. In U.S. Geological Survey, N. US Geological Survey, pp. 2014-3038.

Jonnalagadda, S. B. and Mhere, G. (2001): Water quality of the odzi river in the eastern highlands of zimbabwe. Water Research 35, 2371-2376.

Begum, A., Ramaiah, M., Khan, I., \& Veena, K. (2009). Heavy metal pollution and chemical profile of Cauvery River water Journal of Chemistry, 6 (1), 47-52.

EPA (2012). pH in Water: Monitoring and Assessment, Water Quality Condition. The United States Environmental Protection Agency, $5: 4$

Squires, L. and Sinnu, S. N. (1986) Effects of water quality and season on diatom community structure in the Damour River Lebanon. Hydrobiologia 133, 127-141.

Perl man, H. (2014). Electrical Conductivity and Water. The USGS Water Science School.

El Shakour, E.H.A., \& Mostafa, A. (2012). Water quality assessment of river Nile at Rosetta branch: impact of drains discharge. Middle-East Journal of Scientific Research, 12 (4), 413-423.

Mostafa, M. K. and Peters, R. W. (2015). Use River Pollutant Modeling to Simulate and Predict the Change in the Damietta Branch Water Quality before and after Construction of the Ethiopian Dam. Journal of Environmental Protection, 6: 935-945.

Ma, B.; Jin, M.; Liang, X. and Li, J. (2019). Application of environmental tracers for investigation of groundwater mean residence time and aquifer recharge in fault-influenced hydraulic drop alluvium aquifers. Hydrology and Earth System Sciences, 23(1):427-446.

El-Sheltawy, H. M.; Morsy, A. S.; ElLithy, A. S.; Labib, M. A.; Maree, S. H.; Ahmed, D. F.; Mohamed, E. A.; Saleh, R. M.; Korany, K. H. and Abo El-Azm, M. A. (2007): Environmental Monitoring of Water Quality of River Nile. 2nd International Conference on Environmental Engineering. (Ain Shams University: Cairo, Egypt).

Awadallah, R. M. and Moalla, S. M. N. (1996): Seasonal variation of High Dam lake water. Journal of Environmental Science and Health Part A-Toxic/Hazardous Substances \& Environmental Engineering 31, 731-746.

Ogrinc, N.; Tamše, S.; Zavadlav, S.; Vrzel, J. and Jin, L. (2019). Evaluation of geochemical processes and nitrate pollution sources at the Ljubljansko polje aquifer (Slovenia): A stable 
isotope perspective. Science of the Total Environment, 646:1588-1600.

Robards, K., I. D. Mckelvie, R. L. , Benson, P. J. Worsfold, N. J. Blundell And H. Casey. (1994). Determination of Carbon, Phosphorus, Nitrogen and Silicon Species in Waters. Analytica Chimica Acta 287 (3): 147 - 90.

Ibrahim, S.A. and Tayel, S.I. (2005): Effect of heavy metals on gills of tilapia ziilli inhabiting the River Nile water (Damietta branch and ElRahawey drain, Egypt Journal of. Aquaculture.
Biology. \&fish., 9(2): 111-128.

Wepener, V. Van Vuren, J.H.J. and Preez D.U., H.H. (2001): uptake and distribution of a copper, iron and zinc mixture in a gill liver and plasma of fresh water toleost,tilapia sparrmanii. Water ,27(1),99-108.

Giller, K. E., Witter E. and Mcgrath S. P. (1998): Toxicity of heavy metals to microorganisms and microbial processes in agricultural soils: a review. Soil Biology and Biochemistry 30 (10 - 11): 1389 - 1414.

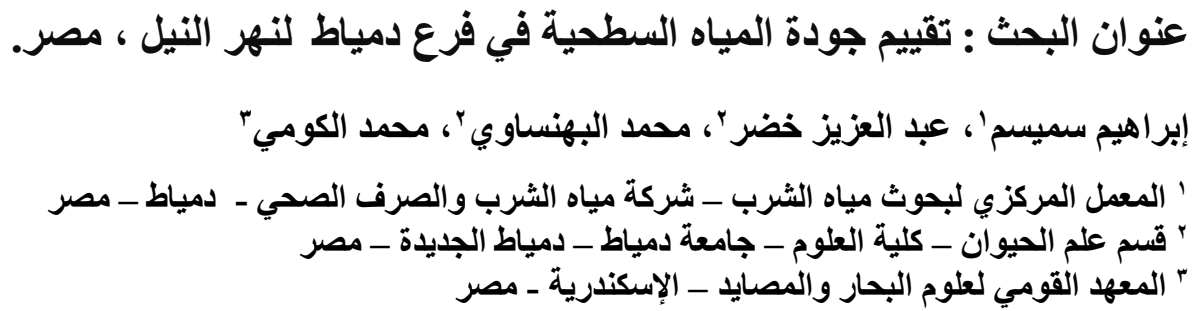

تهذف هذه الدراسة إلى تقييم جودة المياه السطية في جزء من نهر النيل بفرع دمياط عن طريق قياس

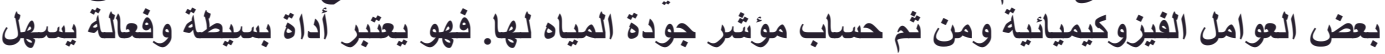

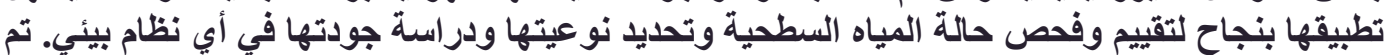

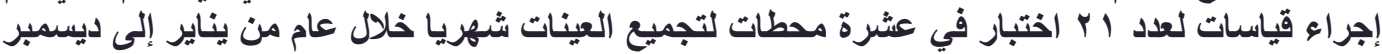

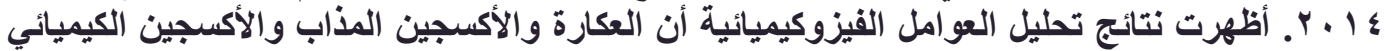

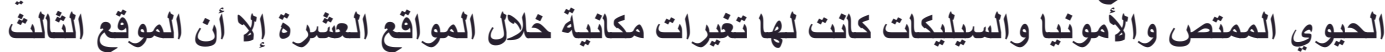

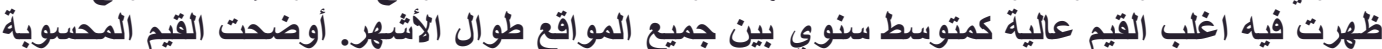

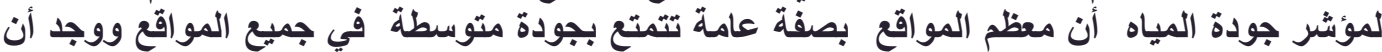

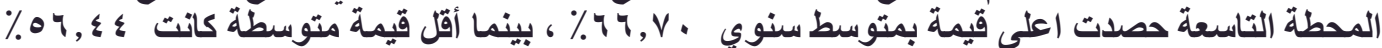

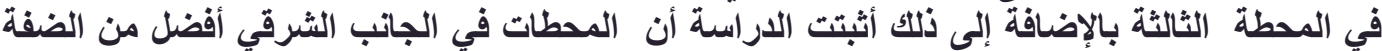

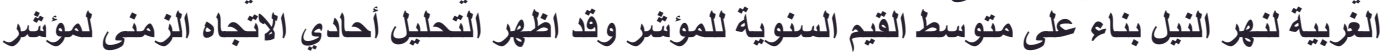

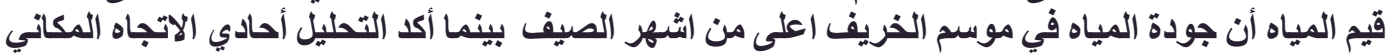

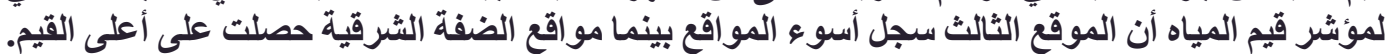

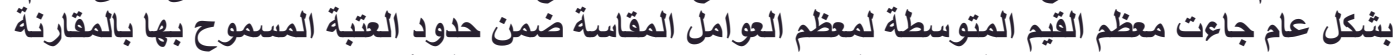
مع المواصفات والمعايير البيئية المصرية ويعتبر مؤشر جودة المياه آلية وأداة مفيدة للرصد المثلة المنتظه. 